\title{
The Cultural and Historical Significance of Kalanga Place Names in Midlands Province of Zimbabwe
}

\author{
*Vimbai Moreblessing Matiza \\ Department of African Languages and Culture \\ Midlands State University, Zvishavane, Zimbabwe \\ Email:matizavimbo@gmail.com/matizavm@staff.msu.ac.zw \\ and \\ Limukani T. Dube \\ Department of African Languages and Culture \\ Midlands State University, Zvishavane, Zimbabwe \\ Email: limmsom.dubez@gmail.com
}

\begin{abstract}
The discipline of onomastics is still at its infancy yet it constitutes a very important aspect of the day to day survival of a people in the society. Naming is part of oral tradition in African societies, people were never used to write and record things but rather their names. This means that names are a historical record that would carry some aspects of a people's way of life which include their history, beliefs and customs among others. On the same note, Midlands Province constitute of people from different backgrounds mainly Shona and Ndebele. Of interest to this research is the presence of the Kalanga people through some toponyms that are found in the area. In light of this view, this study therefore seeks to identify and unlock the culture and history embedded in these names by looking at the significance of Kalanga place names in Midlands Province. The study argues that place names or toponyms of any people carry with them a history, meaning and significance to particular people that name the places, thus studying the place names in this community can be a valuable tool of unpacking the history surrounding the Kalanga people in Midlands Province in Zimbabwe. Guided by the Afrocentric paradigm, specifically nommoic creativity tenant, the study seeks to explore the cultural and historical significance of Kalanga toponyms in Midlands Province.
\end{abstract}

Keywords: Onomastics, historical record, significance, Kalanga place names, function, cultural, Midlands Province

\section{INTRODUCTION}

Place names or toponyms have a direct connection to historical reality and preserve fascinating intimations about the culture of those who use the names. Onomastics studies names and in this field, toponymy is the technical term that refers to a place name, an appropriate name that refers to a place. Onomastics is of great significance to human existence, as people value names of people and places. Names either of people or places are used as tags of identifying people, places or things and are similarly historical witnesses of how and why various places are named. Various scholars concur that toponyms provide cherished discernment into the history of a particular region and a particular people. Crystal (2003) posits that place names can be a source of information on a society's history and past events. The society in a particular place determines the type of names given to an entity. Like personal names, toponyms have social significance for the people who name and those who live in the places that are named. Also like personal names geographical names or toponyms mirror the historical, cultural, social, political and economic factors of a given place. Toponyms are therefore in various ways trails that the society can trace to see where they come from.

Mamvura (2014) acknowledges that giving a name to a place is not an end in itself. It is rather, also embedded in the politics of identity. Which means that when a place is given a Kalanga name for example there are some historical and cultural elements that are associated with the identity of the Kalanga people. 
Helleland (2012) also examines the role of place names as identity markers from both an individual and social points of views. This illustrates that place names prompt some mental relationships between those who use the concerned place and the named landscapes. Thus place names should not be viewed as being merely names but as serving a particular purpose in a community and among the people that name the places. Robins cited in Nhongo and Masuku (2012) articulating the importance of place names of any language and culture says that languages are not mere collections of labels or nomenclature attached to pre-existing bits and pieces of the human world, but that each speech community lives in somewhat different world from that of others, and that these differences are both realized in parts of their cultures and revealed and maintained in parts of their languages through naming. Place names therefore contribute to the feeling of belonging to an area and to a social group within that particular area. So despite the fact that the Midlands Province being central as it is comprises of people from different belongings, some Kalanga place names in the area gives the people a sense of belonging through some place names used in the Province.

\section{Nommoic creativity}

This article is guided largely by the Afrocentric theory. According to Asante (2007) Afrocentricity is a paradigmatic intellectual perspective that privileges African agency within the context of African history and culture trans-continentally and trans-generationally. This means that the quality of location is essentially to any analysis that involves African culture and behaviour whether literary or economic, whether political or cultural. In this regard it is the crystallisation of a critical perspective on facts. Thus the study of place names of the Kalanga people in the Midlands Province needs to be done basing on their perspective as the name givers of these places.

Asante (2007: 108) defines the Afrocentric idea by the following five crucial points. Afrocentricity is first of all defined by an intense interest in psychological location as determined by symbols, motifs, rituals, and signs. Also Afrocentricity is a paradigm that is defined by a commitment to finding the subject-place of Africans in any social, political, economic, or religious phenomenon with implications for the issues of art, music, and literature. Afrocentricity also furthers a defence of African cultural elements as historically valid in the context of art, music and literature. Thus Kalanga toponyms in the Midlands Province are a reservoir of a valid history of their culture. Furthermore, Afrocentricity pushes for a celebration of centeredness and agency and a commitment to lexical refinement that eliminates pejoratives about Africans or other people and finally a powerful imperative from historical sources to revise the collective text of the African people.

Afrocentricity as a theoretical framework also has numerous principles as outlined by Gray (2001) which include Nommoic creativity which is the principle of Afrocentricity that will mainly underpin this study. Nommoic creativity is mainly concerned with creating words and the strategic creation of concepts. Gray (2001:103) states that Nommoic creativity 'contains within it the understanding that words contain power, and used rightly, words can achieve and accomplish what many strong hands, arms, legs and backs cannot do.' Thus the study is guided by the philosophy that names given to the places by the people in Midlands Province are not just empty but carry some values, meanings and are thus significant to the culture and history of the Kalanga people.

\section{Historical background of the Kalanga people}

This section attempts to give a history of the Kalanga people. In doing so, the general origin of these people is explored here. The Kalanga people originate in the North East Africa region, specifically the Sudan-Egypt-Ethiopia region. Like many Bantu groups they trekked from the North down South, finally settling in the region now called Southern Africa. The difference of the Kalanga people with other groups is that they settled Africa south of the Zambezi over two millennia ago. By 100AD, they had already settled in the lands now called Zimbabwe, Mozambique, South Africa and Botswana with most groups arriving between 500 and 1700 years later. By the earliest centuries of the Christian era (500AD) the Kalanga has established what archaeologists have called the Leopard's Kopje Culture. It was an Iron Age sequence culture which was the first in Sub-Saharan Africa to practice mixed farming, mine smelt and trade in gold, copper and iron. By 1000AD, the Kalanga had become a sophisticated people, establishing 
the first city-state in Sub-Saharan Africa, the Maphungubgwe City, on the confluence of the Limpopo and Shashe Rivers. At Maphungubgwe they traded in gold and archaeologists have found several other artefacts made from the precious mineral there. The most famous being the Golden Rhino which now forms order of Maphungubgwe, South Africa's highest national honor.

Furthermore, from Maphungubgwe the Kalanga expanded their state, moving to and constructing Great Zimbabwe, and later Khami. In all these areas they carried on their industries and trade. They traded with the Arabians, Chinese, Ethiopians, Portuguese and Phoenicians. It has been suggested by one writer Gayre (1972) that much of the gold that found its way into that Solomonic Temple and Palace mentioned in the Bible originated among the Kalanga in what later became Zimbabwe. The Zimbabwe Civilisation epitomised by Maphungubgwe, Great Zimbabwe and Khami- three of the man-made UNESCO World Heritage site in Southern Africa can be classified as the greatest civilization ever established in Africa south of Sahara.

On the political side, the Kalanga established the greatest kingdoms ever established in Africa south of Sahara both in terms of power, wealth and expanse. They established the Monomutapa Kingdom which swept from the Zambezi to the Makhado mountains (Luis Tritchardt) north to south, and from the Tendankulu (now Pungwe River) in the middle of Mozambique to the Makadikadi Salt Pans on the boundary of the Kalahari Desert, east west. The Monomutapa Kingdom which existed for about 500 years (1000 -1500) as the greatest polity in Southern Africa, later disintegrated as a result of external attacks and internal decay.

\section{Cultural and historical significance of toponyms}

Letsoela, (2015:60) in explaining the significance and vitality of place names argues that:

naming is not just an act of linguistic labelling by which speakers of a language identify the entities they are referring to in the real or imaginary world. A name is not chosen arbitrarily but is chosen based on a combination of socio-cultural factors. This is because language cannot be divorced from culture, for it is through language that speakers reflect their cultural and sociolinguistic etiquette.

Letsoela (2015) in the above quotation highlights how toponyms of any people and region are crucial and are intertwined with the particular people's culture, language as well as their history. Therefore, toponyms are socially and culturally significant to a people and studying them can be a vital tool of exploring the culture of the people. Dorion cited in Hlophe (2002) also argues that geographical names reveal significant cultural as well as environmental aspects of a community's identity. Place names can also be of great help in the endeavor to understand the culture of the people who occupy particular places. Ormeling (2007:25) argues that; "generally, names are of immense significance in African societies. Toponyms fulfill the task of identifying localities thereby distinguishing them from one another." Toponyms thus are of social significance to different societies. Snodia, Mnguti and Mutami, (2010:15) concur with Ormeling's view of viewing place names as not just meaningless names but as of cultural and societal significance as they argue that; "although the basic function of names has been that of providing a useful label to things so that they can be differentiated, they however also have sentimental literary, religious and cultural significance." Because toponyms bond societies to the setting they provide a vital comprehension into the society's traditional way of life thus their culture.

Crystal cited in Chauke (2015) is of the opinion that the various names that societies and people accord their settings and places offer a distinctive source of evidence about a society's history, beliefs and values. The significance of place names to various societies is also underscored by Chabata (2012:30) in his argument that:

the socio-cultural aspect cannot be left out of consideration and it is commonly agreed, that toponyms belong to the immaterial cultural heritage of mankind; toponyms enable us to take a look at the times when the places were named, they give us insight into the original intentions why this name was given, under which socio-cultural conditions a social community coined this place name. 
Thus place names or toponyms are of great cultural significance. Toponyms also embody a unique characteristic of being part of a community's cultural heritage. Walt cited in the United Nations Group of Experts on Geographical Names (UNGEGN) (2015:17) posits that; "every place name tells a story that is relevant to the culture that bestowed the name." Toponyms or place names are of great importance to the history and culture of any people the Kalanga being of no exception as Simelane-Kalumba (2014) asserts that naming practices are vital among the Kalanga people as they mirror the cultural values and traditions of their everyday experiences. According to the UNGEGN (2015) toponyms could be considered as prized intangible cultural heritage of a people. Guma (2001) is of the opinion that a study of names that is onomastics is of interest as names are also a socio-cultural analysis of historical happenings and place names are indications of a people's history and provide a unique perspective for studying the historical as well as cultural heritage of particular places as well as people.

Toponyms provide significant insight into the history of a particular region and a people. Bigon (2011:12) in elucidating on the historical relevance of place names posits that;

place names are reminders of who we are, and whence we came, and are a rich source of information, about a region's history. [They] also form an integral part of a nation's cultural and linguistic heritage, [......].[and] in many regions, they reveal the chronology of exploration and settlement.

Place names are thus not given to sites for the sake of naming them but to help in the comprehension of the history of the local people settled in particular areas, in this case Midlands Province being the place in question. Hlophe (2002:25) asserts that:

names in Africa and all over the world for both individuals and places are not mere tags. They carry with them certain meanings. In the case of places, they reflect a particular history of a given people, either residing in the area or those with some link with the area.

Toponyms of any region are to a large extent a historical demonstration of a particular region and they assist to inform us about the past of a people in any region. Curchin (2011) posits that the study of early place names can pay impressive dividends in reconstructing the language history of any region, thus place names are an important starting point for historical studies of a region. Because toponyms in essence possess some kind of a conservative quality remaining even for a long time after their original meaning has somewhat been forgotten they thus can serve a vital linguistic function of preserving traces of all the language group that once settled in a particular region. Medway and Warnaby (2014) posit that toponym is a true mirror of the linguistic history of any region and ultimately a precise reflection of their history in general. Klugah (2013) is of the idea that the African people normally preserve their history in different oral forms such as songs, narratives as well as naming processes. Thus toponymic studies in Africa are vital in that they can be employed to unravel the history of the African people in their regions. Mushati (2013) in his study of place names in Masvingo in Zimbabwe argues that the street names in this town comprise a source of history as they bind particular aspects of history to recollection making sure that the history is conserved and handed down from one generation to the next. They also enable a psychological reconnection with the war of liberation in Zimbabwe and in this way preserving a vital history of the people of Zimbabwe.

According to the UNGEGN (2015:15) place names in various African states serve a crucial function and are of great significance. The above article gives an example of Botswana and the function of place names in this African state when they state that:

geographical place names in Botswana reflect the languages spoken in the country, with reference to about (80) dialects. The derivation of these names signifies the historical events, the languages and history behind these names from one basis of Botswana's culture and heritage. Most of the names in all the regions of Botswana have maintained cultural background despite the different dialects. 
When one takes into consideration the fact that many toponyms have been created as descriptions of the particular area or place in question, it is therefore without doubt that place names provide vital material of vast historic value to any society. Ndimande-Hlongwa (2015) argues that indigenous place names are key in preserving living heritage and indigenous knowledge and that the oral history of KwaZulu -Natal in South Africa is largely preserved in various indigenous place names, and that indigenous place names are crucial elements in preserving cultural traditions as well as the indigenous knowledge systems of the Zulu people in this region. Helleland cited in Ndimande-Hlongwa (2015: 45) is also of the idea that;

place names are coined as descriptions of the features or of circumstances that influenced the naming process, they are vital for the knowledge of our past. They are parts of the history of a given area and if they are correctly interpreted, reveal details of the name-givers' understanding of the named place at the time when the name was coined. Thus names may be viewed as a historical oral or written text of the landscape and the people who used the landscape.

Thus Kalanga place names that are found in Midlands Province reflect on the past experiences of the Kalanga people hence substantiating the idea that the province is also home for the group. The next section therefore is going to discuss and analyse Kalanga place names that are found in the province.

\section{Cultural and historical significance of Kalanga toponyms in Midlands Province}

Names that are going to be discussed under this section are Kalanga toponyms which are found in the Province which have been transphonologised to suit the Ndebele and Shona people since they are dominant groups in the province and yet their origins in terms of cultural and historical significance are from Kalanga. The likes of those names include Chiundura, Ntihabezi and Mkoba. Other names to be discussed include Tjingababili Nkalanga, Nkoboli, Gweru and Bilashaba.

\section{Chiundura - Tjibundule (Moyo totem)}

To start with, Chiundura is a place that is argued to have been bestowed on the place following Tjibundule (Kalanga) the big spirit medium of the Moyo totem of the Kalanga people. Chiundura is a corrupted Kalanga place name found in Midlands Province. Gwakubo Ndlovu notes that Tjibundule was formerly named Xamuyenanzwa, who was a former army general, part of the Torwa people who later on settled in Matabeleland. Tjibundule is said to be a brutal leader who boasted by saying:

Ndobundula-Nyika yangu ndiyani ungandipiya poni, ndobundula ndikonya

(I am the one who roars here and no one can rule me I am the ruler the one who roars)

As such Tjibundule (Chibundule) means the one who rules. As noted by Moyo (2012) the BuKalanga kingdom used to be huge covering some parts of Midlands, Matebeleland South and some parts of Matabeleland North. Ndlovu (2017) argues that Chibundule used to have a big following and he led his people to the South western parts of Matabeleland where the BaKalanga are currently geographically located. Chibundule just like Mzilikazi conquered the Bushmen and incorporated them into his kingdom. Mosola (1983) points out that Chibundule's kingdom stretched as far from the Kalahari Desert to the side of the Venda reaching Limpopo and Palapye up to Zambezi.

This name is argued to have been bestowed on the place following Tjibundule (Kalanga) of the Moyo totem a big spirit medium of the Kalanga people. This medium was known for predicting things that would happen. Anything that the 'svikiro' would talk about would definitely come to pass. It is against this backdrop that if such a name belonged to a well-known and big medium then the place was once infested by the Kalanga people because it is through these names that people's identities are revealed. To cement the idea that the place was a once dominated by the Kalanga people this spirit medium Tjibundule was of the Moyo totem and chief Chiundura in the area also shares the same totem which is clear evidence the place was once lived by the Kalanga people. 


\section{Gweru}

The place name Gweru is the name of the Midlands capital and is believed to be a Kalanga corrupted name which was changed from Gwilo to Gwelo up until 1982 then finally to Gweru. There are conflicting views given by participants on this place name. Most BaKalanga subscribe to the view given by Kalanga elders who pint out that Gwilo is a Kalanga place name meaning battlefield. Ndlovu (2017) stipulate that former Gwilo used to be a site for military outpost in 1894 which was established by a white man known as Leander Jameson. This was the first war between the whites under the British South African Company and the people from Matabeleland. Hence due to the presence of the BaKalanga in the area the place was named in their language. On the other hand, the Ndebele people note that Gweru was once known as Gwelo a name of a river. It is argued that it used to be a Matebele settlement named after the rivers' steep banks. The presence of Kalanga place names in Midlands province point out that Gweru might have been termed Gwilo since geographically oral renditions note that the BaKalanga used to settle there.

\section{Tjingababili Nkalanga}

The name Tjingababili is a place name of a farm along Matobo road in Gweru. The farm belongs to a man who is Kalanga by origin. The paradox with that name is that the same place name is also found in Plumtree where the Kalanga people are dominated. The name is believed to have come from a story about a man who comes from a faraway country and meets a Swati girl who was the king's daughter. He impregnates that girl and they were sent away. They stayed together for a long time and when they give birth to their first child they named him Tjingababili which means we have come a long way together. / Tjinga-/means for so long, /-babili/meaning just the two of us. Due to migration and in search of greener pastures the BaKalanga are now dislocated and hence the presence of such Kalanga place names in Midlands province. Moreover, it is against this understanding of these names that there are some Kalanga people who are still found in the Midlands Province and probably the dominance of Shona and Ndebele they named their places with Kalanga names to protect their identity.

\section{Nkoboli}

Closer to the above discussed place, is a mountain called Nkoboli which in Kalanga has three meanings. Firstly, the name means vomiting of a new born baby. Secondly when semi dry mealies are pounded in preparation to make bread the process is known as kukobola and lastly in Kalanga when one prepares traditional Marula beer, the process of separating the juice that is found in marula fruits is called kubolola. This mountain is just some few kilometres from the Tjingababili farm. The presence of Kalanga place names in Midlands province portray that the history of the BaKalanga people in the area cannot be overemphasised. The concept of indigenous people naming their places according to their understanding of phenomenon is prevalent here. Thus Krauss (1968) postulates that languages need special love, care, and protection by the communities that want to keep them alive. If indigenous languages are to survive, it is not enough for more children and adults to learn these languages. Environments also must be created in indigenous communities where the indigenous language is used exclusively. The old saying "use it or lose it" goes for indigenous languages as well as a lot of other things. It is in this spirit that these places were named by the people who lived in the area as part and parcel of their life. Nkoboli mountain is said to be spiritual and up to date it is like that. The mountain smokes out which is kukobola which is equated to a child vomiting. When smoke comes out of it the village has to find out from Tjibundule the spirit medium what has to be done in the land. When fire also comes out of the mountain no one was allowed to put out the fire until the spirit medium was consulted. This follows that the area was a dominance of the Kalanga people and the activities done in the place reflect the religious and cultural system of the BaKalanga.

\section{Bilashava - Mbilashaba (Kalanga)}

The above place name is the name of the school in Zvishavane. The name means a red rock rabbit in Kalanga. This name could have been given to the school because of the presence of red rock rabbits in the area. The BaKalanga used to be hunters as noted by the former Chairperson of Kalanga Language 
and Cultural Development Association, hence they had a habit of naming places after their lifestyles. Mbilashaba, is a compound term for mbila (rabbit) and /-shaba/ (red) which is in Lilima, a dialect of Kalanga. The name on its own as noted by one of the participants portray that the BaKalanga used to reside in Midlands province as it is also reflected by the name of the school which has been built where these red rabbits were prominent. The Kalanga people used to be hunters before the government enacted laws that governed and protected wild animals.

\section{Mapungubgwe dam and Mkoba - Nkoba (Kalanga)}

More so the history and culture of the Kalanga people can be traced in Midlands province through the toponyms, Mapungubgwe dam and Mkoba/ Nkoba. Mapungubgwe is a dam and Mkoba / Nkoba is both a location and a primary school in Lower Gweru. A dam known as Mapungubgwe also shares the same name with a nearby mountain where a large number of jackals are found. Historically, the Kalanga are known to be great builders, it is believed that when they moved from the East their first settlement was in Limpopo province in South Africa where it is believed that they built the Mapungubgwe before coming to Zimbabwe where they finally settled. The Moyo clan of the Kalanga tribe are believed to have engineered the building of the major heritage sites like Mapangubgwe, Great Zimbabwe and Khami and that is why the baKalanga would name their places using Kalanga names. On the other hand, is Nkoba which means a doorway in Kalanga. The name Mkoba is a corrupted Kalanga term which came as a result of wanting to accommodate the Shona speaking people who could have difficulties in pronouncing the term otherwise Mkoba is meaningless as noted by one of the participants. The fact that the name Mkoba/Nkoba is used on two places that is as a location and a school means that the Kalanga people who lived in the area had so much attachment to their environment thus naming them in the way that they understand most.

\section{Ntihabezi - Ntiyabezi (Kalanga)}

The other place name that reflects the once dominated Kalanga land in the Midlands Province is Ntihabezi (Kalanga) which is the name of the river in Lower Gweru. The place name means the one that runs away from visitors. It could be as a result of fear of witchcraft or could be greediness but the meaning still stands. As has been shown above, one can clearly be convinced that the Kalanga speaking people once lived in the Midlands but because the language was marginalised it was overshadowed by IsiNdebele that is why most of the terms sound Ndebele but in actual fact there are no such terms in Ndebele.

\section{CONCLUSION}

After all has been said and done, the presence of history of the BaKalanga people in Midlands Province cannot be overemphasised. The paper discusses the cultural and historical significance of Kalanga place names in Midlands Province. The study has established that the place names that are discussed in the paper shows the presence of the Kalanga people in the area. Their history and cultural practices is prevalent through some of the names discussed. The article stresses that there are a number of Kalanga place names in Midlands Province which demonstrate that geographically the BaKalanga used to occupy the Midlands Province as well. The BaKalanga place names reflect the socio-economic, cultural, political and history of the Bakalanga as proven in this article. Place names discussed above have a historical and cultural significance hence place names are reminders of who we are, and whence we came, and are a rich source of information, about a region's history. 


\section{REFERENCES}

Asante, MK. 2007. An Afrocentric Manifesto: Toward an African Renaissance. Philadelphia: Temple University Press.

Bigon, L. 2011. "The Former Names of Lagos (Nigeria) in Historical Perspectives." Names 59 (4):229-240.

Chabata, E. 2012. Feature Names and Identity in Zimbabwe. In Helleland, C, Ore E \& Wikstrom S (eds). Names and Identities, Oslo Studies in Language 4(2), 2012, 1-6(ISSN 1890-9639). http://www. journals.uio.no/osla

Chauke, M.T. 2015. Name Changes in South Africa: An Indigenous Flavour. Anthropologist, 9(1):285293 (2015). Thohoyandou: University of Venda.

Crystal, D.2003. The Cambridge Encyclopaedia of the English Language (2 $2^{\text {nd }}$ ed).Cambridge: Cambridge University Press

Curchin, L.A. 2011. Naming the Provincial landscape: Settlement and Toponymy in Ancient Catalunya. Canada: University of Waterloo.

Gayre, R. 1972. The origin of the Zimbabwean civilisation. Salisbury: Galaxie Press

Gray, C.C. 2001. Afrocentric Thought and Praxis: An Intellectual History. Asmara: African World Press.

Guma, M. 2001.The Cultural Meaning of Names among Basotho of Southern Africa: A Historical and Linguistic Analysis. Nordic Journal of African Studies.10 (3):265-279

Helleland, B. 2012. (a) Names and Identities. In Helleland, C., Ore, C., and Wikstrom, S (eds).Oslo Studies in Language 4(2), 2012. 95-116,http://www.journals.ulo.no/osla.

Helleland, B. 2012. (b) Place Names as Means of Landscape Identity: Paper presented at the symposium on Geographical Names as Part of the Cultural Heritage. Vienna.

Hlophe, D. 2002. SA Names must tell the story of all its people. City Press, Weekly, February 18, 2002, p.9

Klugah, M. 2013.Recounting history through linguistics: A toponymic analysis of Asogli migration narratives. African Journal of History and Culture, Vol. 5(8), pp. 151-159,October 2013. http:// www.academicjournals.org/AJHC.( Accessed on April 16,2018)

Krauss, R. M 1998. Language as a symbolic process in communication. American Scientist, 56, 265-278

Letsoela, P.M. 2015. A Semantic Analysis of Sesotho Place Names: Evidence from Bus Stop Names. International Journal of English Language \& Translation Studies. 3(1),01-08. http://www.eltsjournal. org (Accessed on April 16 2018)

Mamvura, Z. 2014. A Sociolinguistic analysis of school names in selected urban centres during the colonial period in Zimbabwe. (1890-1979). Unpublished PHD thesis, University of South Africa.

Masola, K. 1983. Nhau dzabaKalanga: A History of the Kalanga, Vol 1. Pretoria: University of South Africa. Medway, D, and Warnaby, G. 2014.What's in a name? Place branding and toponymic commodification. Environment and Planning 2014, volume 46, pages 153-167.doi:10.10681a45571.

Moyo, N. E. 2012. The Rebirth of BaKalanga: A manifesto for the liberation of a Great People with a proud history Part 1. Plumtree: Mapungubgwe News Coorpertion.

Mushati, A. 2013.Street naming as author (iz) ing the collective memory of the Nation: Masvingo's Mucheke Suburb in Zimbabwe. International Journal of Asian Social Sciences, 2013, 3(1):69-91

Ndimande-Hlongwa, N. 2015. The role of Indigenous place names in preserving living heritage of the Zulu people in KwaZulu-Natal. Durban: University of KwaZulu-Natal.

Ndlovu, H. 2017. Prospects and challenges of standardising Kalanga orthography. Unpublished MA thesis, Midlands State University.

Nhongo, R., and Masuku J. 2012. Influence of an African language on European place names in Zimbabwe: Is it language corruption, language development or resistance.

Ormeling, F. 2007. "Minority Toponyms-the Western Europe Experience.” In Ormeling's Cartography, edited by E. Heere and M.Storms, 117-124.Netherlands Geographical Studies.

Simenale-Kalumba, P.I. 2014. The Use of Proverbial names among the Xhosa Society: Socio: Cultural approach .Unpublished Masters' Thesis: University of the Western Cape.

Snodia, M., Mnguti, T., and Mutami, N. 2010. "Politically Dialoguing Through the Naming Process: The Case of Colonial Zimbabwe (1890-1980).” J. Pan African Stud. 3(10). UNGEGN 2015. 